\title{
Analisis Pengaruh Pendidikan dan PDRB per Kapita terhadap Jumlah Penduduk Miskin di Provinsi Aceh
}

\author{
Safuridar \\ Fakultas Ekonomi Universitas Samudra \\ e-mail: safuridar@unsam.ac.id \\ Maya Damayanti \\ Fakultas Ekonomi Universitas Samudra \\ e-mail: mayadamayanti45@yahoo.com
}

\begin{abstract}
Abstrak
Tujuan penelitian ini adalah menganalisis pengaruh pendidikan dan PDRB per kapita baik secara parsial maupun simultan terhadap jumlah penduduk miskin di Provinsi Aceh. Data sekunder berupa data pendidikan (rata-rata lama sekolah), PDRB Per Kapita dan Jumlah Penduduk Miskin di Provinsi Aceh tahun 2007-2017. Metode analisis menggunakan analisis regresi linear berganda. Dari hasil pengujian diperoleh bahwa secara parsial, rata-rata lama sekolah berpengaruh negatif tetapi tidak signifikan terhadap jumlah penduduk miskin di Provinsi Aceh; sementara PDRB per kapita berpengaruh negatif dan signifikan terhadapjumlah penduduk miskin di Provinsi Aceh. Secara simultan, rata-rata lama sekolah dan PDRB per kapita berpengaruh signifikan terhadap jumlah penduduk miskin di Provinsi Aceh. Koefisien determinasi menunjukkan bahwa rata-rata lama sekolah dan PDRB per kapita berkontribusi sebesar 84,1 persen terhadap jumlah penduduk miskin; sedangkan selebihnya dipengaruhi oleh variabel-variabel lain yang tidak diteliti dalam model penelitian ini, seperti pengangguran atau produktivitas tenaga kerja.
\end{abstract}

Kata kunci: Pendidikan, PDRB, penduduk miskin.

\section{PENDAHULUAN}

Pembangunan adalah suatu proses perubahan menuju ke arah yang lebih baik dan terus menerus untuk mencapai tujuan, yakni mewujudkan masyarakat Indonesia yang berkeadilan, berdaya saing, maju, dan sejahtera dalam wadah Negara Kesatuan Republik Indonesia. Pembangunan harus diarahkan sedemikian rupa sehingga setiap tahap semakin mendekati tujuan. Kemiskinan merupakan masalah yang dihadapi oleh semua negara di dunia, terutama negara sedang berkembang. Kemiskinan merupakan masalah kompleks yang dipengaruhi oleh berbagai faktor yang saling berkaitan, antara lain tingkat pendapatan masyarakat, pengangguran, kesehatan, pendidikan, akses terhadap barang dan jasa, lokasi, geografis, gender, dan lokasi lingkungan.
Gambaran umum jumlah penduduk miskin di Provinsi Aceh tahun 2012-2017 adalah terjadinya penurunan kemiskinan pada tahun 2013 dibandingkan tahun 2012 yaitu sebesar -7,32 persen; kemudian pada tahun 2014 tingkat kemiskinan meningkat sebesar 4,61 persen. Hal ini terjadi karena meningkatnya jumlah penduduk miskin di daerah pedesaan. Tahun 2016, tingkat kemiskinan mengalami penurunan sebesar $-0,36$ persen (http://aceh.bps.go.id, 2018).

Pendidikan adalah pionir di dalam pembangunan masa depan suatu bangsa. Jika dunia pendidikan suatu bangsa sudah jeblok, maka kehancuran bangsa tersebut tinggal menunggu waktu. Hal ini disebabkan pendidikan yang menyangkut pembangunan karakter dan sekaligus mempertahankan jati diri manusia suatu bangsa. Banyak orang 
miskin yang mengalami kebodohan atau mengalami kebodohan, bahkan secara sistematis. Karena itu, menjadi penting bagi kita untuk memahami bahwa kemiskinan bisa mengakibatkan kebodohan, dan kebodohan jelas identik dengan kemiskinan (Wiguna, 2013). Di Provinsi Aceh, tingkat pendidikan dapat diukur salah satunya dengan rata-rata lama sekolah.

Rata-rata lama sekolah di Provinsi Aceh dari tahun 2012 sampai 2017 mengalami suatu peningkatan (http://aceh.bps.go.id, 2018). Pada tahun 2012, angka rata- rata lama sekolah di Provinsi Aceh sebesar 8,36 tahun. Artinya, penduduk Provinsi Aceh rata-rata bersekolah sampai dengan kelas 3 SMP (belum tamat). Akan tetapi, angka ini masih belum mencapai target pendidikan maksimal 15 tahun atau setara dengan sekolah menengah atas (SMA).

Indikator kesejahteraan penduduk suatu daerah yakni PDRB per kapita (Pratiwi, 2014). Indikator ini menyatakan bahwa apabila pertumbuhan PDRB yang tinggi dan PDRB per kapita tinggi, yang berarti terdapat lebih banyak pekerjaan yang lebih baik dan tingkat pendapatan yang lebih tinggi, serta basis pemungutan pajak yang lebih besar yang memungkinkan pemerintah untuk berbuat lebih banyak bagi masyarakat miskin.

Pendapatan perkapita di Provinsi Aceh berfluktuasi dari tahun ke tahun. Pada tahun 2013 terjadi peningkatan pendapatan sebesar 0,56 persen; sementara PDRB Per Kapita Provinsi Aceh tahun 2013 sebesar Rp. 23.228,747 merupakan angka PDRB Per Kapita tertinggi di Provinsi Aceh. Kemudian pada tahun 2015, PDRB Per Kapita Provinsi Aceh sebesar Rp 22.523,198 merupakan angka PDRB Per Kapita terendah di Provinsi Aceh dengan laju pertumbuhan sebesar -2,62 persen. Hal ini disebabkan karena terjadinya penurunan nilai PDRB dan disertai dengan meningkatnya jumlah penduduk di Provinsi Aceh (http://aceh.bps.go.id, 2018).

Berdasarkan latar belakang tersebut, maka dipandang menarik untuk membahas mengenai jumlah penduduk miskin di Provinsi Aceh. Selain itu, di dalam penelitian ini juga akan dilihat bagaimana pengaruh variabel Pendidikan dan PDRB per kapita terhadap jumlah penduduk miskin di Provinsi Aceh pada tahun 2007-2016. Berdasarkan uraian latar belakang, rumusan masalah dalam penelitian ini adalah: (1) apakah pendidikan dan PDRB per Kapita secara parsial berpengaruh terhadap jumlah penduduk miskin di Provinsi Aceh?; dan, (2) apakah pendidikan dan PDRB per Kapita secara simultan berpengaruh terhadap jumlah penduduk miskin di Provinsi Aceh?

\section{Kemiskinan}

Kotze (dalam Hikmat, 2004) menyatakan bahwa masyarakat miskin memiliki kemampuan yang relatif baik untuk memperoleh sumber melalui kesempatan yang ada. Kendatipun bantuan luar terkadang digunakan, tetapi tidak begitu saja dapat dipastikan sehingga masyarakat bergantung pada dukungan dari luar. Pendekatan pemberdayaan ini dianggap tidak berhasil karena tidak ada masyarakat yang dapat hidup dan berkembang bila terisolasi dari kelompok masyarakat lainnya. Upaya pengisolasian ini menimbulkan sikap pasif, bahkan keadaan menjadi semakin miskin.

Ukuran kemiskinan menurut Nurkse (Arsyad, 2010), secara sederhana dan yang umum digunakan dapat dibedakan menjadi dua pengertian, yaitu kemiskinan absolut, dan kemiskinan relatif. Kemiskinan absolut adalah kondisi seseorang termasuk golongan miskin absolut apabila hasil pendapatannya berada di bawah garis kemiskinan dan tidak cukup untuk menentukan kebutuhan dasar hidupnya. Konsep ini dimaksudkan untuk menentukan tingkat pendapatan minimum yang cukup untuk memenuhi kebutuhan fisik terhadap makanan, pakaian, dan perumahan untuk menjamin kelangsungan hidup. Kesulitan utama dalam konsep kemiskinan absolut adalah menentukan komposisi dan tingkat kebutuhan minimum karena kedua hal tersebut tidak hanya dipengaruhi oleh adat kebiasaan saja, tetapi juga iklim, tingkat kemajuan suatu negara, dan faktor-faktor ekonomi lainnya. Walaupun demikian, untuk dapat hidup layak, seseorang membutuhkan 
barang-barang dan jasa untuk memenuhi kebutuhan fisik dan sosialnya.

Kemiskinan relatif adalah kondisi dimana seseorang termasuk golongan miskin relatif apabila telah dapat memenuhi kebutuhan dasar hidupnya, tetapi masih jauh lebih rendah dibandingkan dengan keadaan masyarakat sekitarnya. Berdasarkan konsep ini, garis kemiskinan akan mengalami perubahan bila tingkat hidup masyarakat berubah sehingga konsep kemiskinan ini bersifat dinamis atau akan selalu ada. Oleh karena itu, kemiskinan dapat dari aspek ketimpangan sosial yang berarti semakin besar ketimpangan antara tingkat penghidupan golongan atas dan golongan bawah. Hal ini berarti semakin besar pula jumlah penduduk yang dikategorikan selalu miskin.

\section{Indikator kemiskinan}

Garis kemiskinan yang digunakan setiap negara berbeda-beda, sehingga tidak ada satu garis kemiskinan yang berlaku umum. Hal ini disebabkan karena adanya perbedaan lokasi dan standar kebutuhan hidup. Ukuran kemiskinan dipertimbangkan berdasarkan pada norma pilihan, dimana norma tersebut sangat penting terutama berkaitan dengan hal pengukuran yang didasarkan atas konsumsi (consumption based poverty line). Karenanya menurut Kuncoro (2006), garis kemiskinan yang didasarkan pada konsumsi terdiri dari dua elemen. Elemen pertama adalah pengeluaran yang diperlukan untuk memberi standar gizi minimum dan kebutuhan mendasar lainnya; dan, elemen kedua adalah jumlah kebutuhan yang sangat bervariasi yang mencerminkan biaya partisipasi dalam kehidupan sehari-hari.

Garis kemiskinan dibedakan menurut tempat dan waktu, jadi setiap daerah baik di desa maupun di kota memiliki nilai yang berbeda-beda dan umumnya nilai ini bertambah pada norma tertentu. Pilihan norma tersebut sangat penting terutama dalam hal pengukuran kemiskinan. Batas garis kemiskinan dibedakan antara desa dan kota. Perbedaan ini sangat signifikan antara desa dan kota, hal ini disebabkan pada perbedaan dan kompleksitas di desa dan di kota.

\section{Penyebab Kemiskinan}

Kuncoro (2006) mencoba mengidentifikasi penyebab kemiskinan dipandang dari sisi ekonomi. Pertama, secara mikro, kemiskinan muncul karena adanya ketidaksamaan pola kepemilikan sumberdaya yang menimbulkan distribusi pendapatan yang timpang; dimana penduduk miskin hanya memiliki sumberdaya dalam jumlah terbatas dan kualitasnya rendah.

Kedua, kemiskinan muncul akibat perbedaan dalam kualitas sumberdaya manusia. Kualitas sumberdaya manusia yang rendah berarti produktivitasnya rendah, yang pada gilirannya upahnya rendah. Rendahnya kualitas sumberdaya manusia ini karena rendahnya pendidikan, nasib yang kurang beruntung, adanya diskriminasi, atau karena keturunan. Terakhir, kemiskinan muncul akibat perbedaan akses dalam modal.

\section{Pendidikan}

Jenjang pendidikan adalah tahap pendidikan yang ditetapkan berkelanjutan, yang ditetapkan berdasarkan tingkat perkembangan peserta didik, tingkat kerumitan bahan pengajaran dan cara menyajikan bahan pengajaran. Jalur pendidikan yang ada di Indonesia meliputi pendidikan formal, pendidikan nonformal, dan pendidikan informal.

Pendidikan formal merupakan jalur pendidikan yang terstruktur dan berjenjang yang terdiri atas pendidikan dasar, menengah dan tinggi; dengan uraian:

1. Pendidikan dasar, merupakan jenjang pendidikan yang melandasi pendidikan menengah. Pendidikan dasar berbentuk Sekolah Dasar (SD) dan Madrasah Ibtidaiyah (MI) atau bentuk lain yang sederajat, serta Sekolah Menengah Pertama (SMP) dan Madrasah Tsanawiyah (MTs), atau bentuk lain yang sederajat.

2. Pendidikan menengah, merupakan lanjutan pendidikan dasar. Pendidikan menengah terdiri atas pendidikan menengah umum dan pendidikan menengah kejuruan. Pendidikan menengah berbentuk Sekolah Menengah Atas (SMA), Madrasah Aliyah (MA), Sekolah Menengah Kejuruan 
(SMK), dan Madrasah Aliyah Kejuruan (MAK), atau bentuk lain yang sederajat.

3. Pendidikan tinggi, merupakan jenjang pendidikan setelah pendidikan menengah yang mencakup program pendidikan diploma, sarjana, magister, spesialis, dan doktor yang diselenggarakan oleh pendidikan tinggi. Perguruan tinggi dapat berbentuk akademik, politeknik, sekolah tinggi, institut, atau universitas.

Pendidikan nonformal adalah jalur pendidikan di luar pendidikan formal yang dapat dilaksanakan secara terstruktur dan berjenjang. Pendidikan nonformal diselenggarakan bagi masyarakat yang memerlukan layanan pendidikan yang berfungsi sebagai pengganti, penambah, dan/atau pelengkap pendidikan formal dalam rangka mendukung pendidikan sepanjang hayat. Pendidikan ini meliputi pendidikan kecakapan hidup, pendidikan anak usia dini, pendidikan kepemudaan, pendidikan pemberdayaan perempuan, pendidikan keaksaraan, dan lain-lain.

Pendidikan informal adalah jalur pendidikan keluarga dan lingkungan yang berbentuk kegiatan belajar secara mandiri. Hasil pendidikan formal diakui sama dengan pendidikan formal dan nonformal setelah peserta didik lulus ujian sesuai dengan standar nasional pendidikan.

Menurut Badan Pusat Statistik Aceh 2017, salah satu komponen pendidikan yang digunakan dalam penghitungan IPM adalah rata-rata lama sekolah (RLS). Rata-rata lama sekolah adalah jumlah tahun belajar penduduk usia 15 tahun ke atas yang telah diselesaikan dalam pendidikan formal (dengan asumsi pada saat berusia 15 tahun proses pendidikan seseorang sudah berakkhir). Indikator ini merupakan kombinasi dari angka partisipasi sekolah, jenjang dan jenis pendidikan yang pernah atau sedang diduduki, ijazah tertinggi yang pernah dimiliki dan tingkat/kelas tertinggi yang pernah/sedang diduduki.

\section{METODE PENELITIAN}

\section{Analisis Regresi Berganda}

Metode analisa data yang digunakan dalam penelitian ini adalah analisis regresi berganda. Menurut Sugiyono (2013), regresi berganda digunakan bila peneliti bermaksud meramalkan bagaimana keadaan (naik atau turunnya) variabel dependen (kriterium), bila dua atau lebih variabel independen sebagai faktor prediktor dimanipulasi (dinaikturunkan nilainya). Jadi analisis regresi berganda akan dilakukan bila jumlah variabel independennya minimal dua.

Pengujian hipotesis pada penelitian ini menggunakan analisis regresi linier berganda. Analisis ini digunakan untuk mengetahui pengaruh beberapa variabel independen (X) terhadap variabel dependen (Y). Analisis linier berganda dilakukan dengan uji koefisien determinasi, uji t, dan uji F. Model penelitian ini diformulasikan:

$$
\log Y=a+\beta_{1} \log X_{1}+\beta_{2} \log X_{2}+\mu_{i}
$$

dimana $\log Y$ merupakan Jumlah Penduduk Miskin; $\alpha$ adalah Konstanta; $\beta$ adalah Koefisien Regresi dari variabel independen; $\log X_{1}$ adalah Pendidikan; $\log X_{2}$ adalah PDRB per Kapita; dan, $\mu_{i}$ adalah error.

Menurut Priyatno (2011), regresi logaritma dilakukan dengan syarat-syarat: (a) data yang digunakan berjenis data interval sampai rasio; (b) distribusi data tidak normal; (c) merupakan transformasi dari persamaan regresi linier; dan, (d) grafik mengikuti model "steady growth function".

\section{Uji Parsial (Uji t-Statistik)}

Menurut Ghozali (2011), uji t-statistik dilakukan untuk menunjukkan seberapa jauh pengaruh satu variabel penjelas atau independen secara individual dalam menerangkan variasi variabel dependen.

Prosedur melakukan uji $\mathrm{t}$ mula-mula adalah bila jumlah degree of freedom $(d f)$ adalah 20 atau lebih, dan derajat kepercayaan sebesar 5 persen, maka Ho yang menyatakan $\beta i=0$ dapat ditolak bila nilai $t$ lebih besar dari 2 (dalam nilai absolut). Dengan kata lain, menerima hipotesis alternatif yang menyatakan bahwa suatu variabel independen secara individual mempengaruhi variabel dependen.

Prosedur selanjutnya adalah membandingkan nilai $t$-statistik dengan titik kritis menurut tabel. Apabila nilai $t$-statistik hasil 
perhitungan lebih tinggi dibandingkan dengan nilai t-tabel, maka ditentukan menerima hipotesis alternatif yang menyatakan bahwa suatu variabel independen secara individual mempengaruhi variabel dependen.

\section{Uji Simultan (Uji F)}

Uji ini pada dasarnya adalah untuk menunjukkan apakah semua variabel bebas yang dimasukkan dalam model mempunyai pengaruh secara bersama-sama atau simultan terhadap variabel terikat. Prosedur pelaksaaan uji ini adalah awalnya menentukan hipotesis yang akan diuji $\left(\mathrm{H}_{0}\right.$ dan $\left.\mathrm{Ha}\right)$; lalu menentukan level of significance (a) tertentu; selanjutnya, menentukan kriteria pengujian dengan membandingkan nilai $F$-tabel dan F-hitung; dan, terakhir, adalah menarik kesimpulan.

\section{Koefisien Determinasi $\left(\mathbf{R}^{2}\right)$}

Koefisien determinasi $\left(\mathrm{R}^{2}\right)$ pada intinya mengukur seberapa jauh kemampuan model dalam menerangkan variasi dari variabel dependen. Nilai koefisien determinasi adalah antara nol dan satu. Nilai $R^{2}$ yang kecil berarti kemampuan variabel-variabel independen dalam menjelaskan variasi variabel dependen amat terbatas. Nilai $R^{2}$ yang mendekati satu berarti variabel-variabel independen mampu memberikan hampir semua informasi yang dibutuhkan untuk memprediksi derajat variasi variabel dependen (Ghozali, 2011).

\section{HASIL ANALISIS}

\section{Kemiskinan di Provinsi Aceh}

Selama kurun waktu tahun 2006-2017 pada periode tahun-tahun tertentu kemiskinan mengalami fluktuasi. Perkembangan kemiskinan yang paling tinggi di Provinsi Aceh terjadi pada tahun 2014 yaitu sebesar 4,61 persen. Tahun 2008-2010 tingkat kemiskinan mengalami penurunan masing-masing sebesar $-11,42$ persen, $-6,96$ persen, dan $-3,47$ persen. Selanjutnya tahun 2011-2012 perkembangan kemiskinan mengalami peningkatan masingmasing sebesar 3,82 persen, dan 1,59 persen. Meningkatnya perkembangan kemiskinan pada tahun 2011-2012 ini disebabkan karena tingginya tingkat pengangguran di beberapa Kabupaten kota di Provinsi Aceh. Pada tahun
2013 perkembangan kemiskinan mengalami penurunan dibandingkan tahun 2012, yaitu sebesar -7,32 persen; untuk selanjutnya perkembangan kemiskinan yang terendah terjadi pada tahun 2016 sebesar -0,36 persen.

Kondisi tingginya angka kemiskinan ini merupakan salah satu indikator tingkat kesejahteraan masyarakat Aceh yang masih terjerat dangan persoalan kemiskinan. Jika dibandingkan dengan aliran dana APBA belasan triliun yang mengalir ke Provinsi Aceh tiap tahunnya, maka berlimpahnya anggaran masih belum berdampak positif terhadap penurunan angka kemiskinan. Termasuk persoalan pengangguran yang merupakan salah satu penyebab kemiskinan.

\section{Pendidikan (Rata- Rata Lama Sekolah) di Provinsi Aceh}

Salah satu komponen pendidikan yang digunakan dalam penghitungan IPM adalah rata-rata lama sekolah (RLS). Rata-rata lama sekolah adalah jumlah tahun belajar penduduk usia 15 tahun keatas yang telah diselesaikan dalam pendidikan formal (dengan asumsi pada saat berusia 15 tahun proses pendidikan seseorang sudah berakkhir. Indikator ini merupakan penghitungan dari kombinasi angka partisipasi sekolah, jenjang dan jenis pendidikan yang pernah/sedang diduduki, ijazah tertinggi yang pernah dimiliki dan tingkat /kelas tertinggi yang pernah/sedang diduduki.

Angka rata-rata lama sekolah di Provinsi Aceh pada tahun-tahun tertentu mengalami fluktuasi. Pada tahun 2007 angka rata- rata lama sekolah di Provinsi Aceh sebesar 8,50 tahun, yang berarti penduduk Aceh rata-rata bersekolah sampai dengan kelas 3 SMP (belum tamat). Sedangkan pada tahun 2011, 2012 dan pada tahun 2013, angka rata-rata lama sekolah di Provinsi Aceh mengalami penurunan masing-masing sebesar 8,32 tahun 8,36 tahun dan 8,44 tahun. Pada tahun 2015, angka rata-rata lama bersekolah mengalami peningkatan sebesar 8,87 tahun, atau artinya rata-rata lama bersekolah penduduk Aceh yang berusia 15 tahun ke atas adalah pada jenjang kelas 3 sekolah menengah pertama (SMP). 
Akan tetapi angka-angka tersebut masih belum mencapai target pendidikan maksimal 15 tahun atau setara dengan sekolah menengah atas (SMA). Sarana pendukung dunia pendidikan seperti jumlah sekolah maupun tenaga pendidik secara kuantitas maupun kualitas masih harus terus diperbaiki dan ditingkatkan.

\section{Perkembangan PDRB Per Kapita di Provinsi Aceh}

Perkembangan PDRB per kapita di Provinsi Aceh masih kurang stabil dan terlihat adanya fluktuasi dari tahun ke tahun. Pada tahun 2007, PDRB per kapita adalah sebesar Rp. 26.158 dan merupakan angka PDRB per kapita tertinggi di Provinsi Aceh. Tetapi pada tahun 2008 terjadi penurunan sebesar $-6,78$ persen dengan PDRB per kapita menjadi sebesar Rp. 24.383. Kemudian pada tahun 2015, PDRB per kapita sebesar Rp. 22.523 dengan pertumbuhan sebesar $-2,62$ persen; dan, ini angka PDRB per kapita terendah di Provinsi Aceh.

\section{Pengaruh Pendidikan dan PDRB Per Kapita atas Jumlah Penduduk Miskin}

Untuk mengetahui seberapa besar pengaruh pendidikan dan PDRB secara parsial terhadap kemiskinan di Provinsi Aceh, maka penelitian ini menggunakan uji $t$ statistik. Pengujian ini dilakukan untuk menguji apakah variabel independen (ratarata lama sekolah dan PDRB per kapita) berpengaruh secara parsial terhadap variabel dependen (jumlah penduduk miskin).

Tabel 1. Hasil Analisis Regresi Berganda

\begin{tabular}{|c|c|c|c|c|c|}
\hline \multirow[t]{2}{*}{ Model } & $\begin{array}{l}\text { Unstandardized } \\
\text { Coefficient }\end{array}$ & $\begin{array}{l}\text { Standardized } \\
\text { Coefficients }\end{array}$ & $\begin{array}{l}\text { Standardized } \\
\text { Coefficients }\end{array}$ & \multirow[t]{2}{*}{$\mathrm{t}$} & \multirow[t]{2}{*}{ Sig. } \\
\hline & B & Std. Error & Beta & & \\
\hline Constant & $-2,798$ & 1,104 & & $-2,534$ & 0,039 \\
\hline Pendidikan & $-0,135$ & 0,174 & $-0,122$ & 0,778 & 0,462 \\
\hline PDRB & $-1,346$ & 0,240 & $-0,877$ & 5.605 & 0,001 \\
\hline $\mathrm{F}$ & 18,515 & & & & \\
\hline Sig. & 0,002 & & & & \\
\hline R Square & 0,841 & & & & \\
\hline
\end{tabular}

Sumber: Data primer (diolah), tahun 2018

Pengujian regresi linier berganda dilakukan dengan menggunakan SPSS versi 17.0. Berdasarkan hasil analisis regresi pada Tabel I, dapat diformulasikan persamaan:

$$
\log Y=-2,798-0,135 \log X_{1}-1,346 \log _{2}
$$

Dari persamaan regresi itu dijelaskan sebagai berikut:

- Konstanta memiliki nilai sebesar -2,798. Hal ini menunjukkan bahwa jika variabel rata-rata lama sekolah dan PDRB per kapita nilainya tetap atau konstan, maka jumlah penduduk miskin sebesar minus 2,798.

- Koefisien regresi dari variabel pendidikan rata-rata lama sekolah $\left(\mathrm{X}_{1}\right)$ nilainya adalah minus 0,135 . Hal ini menunjukkan bahwa jika variabel pendidikan rata-rata lama sekolah mengalami kenaikan sebesar 1 persen, maka jumlah penduduk miskin akan mengalami penurunan sebesar 0,135 , dengan asumsi bahwa variabel-variabel independen lainnya bersifat tetap atau konstan.

- Koefisien regresi dari variabel PDRB per kapita $\left(\mathrm{X}_{2}\right)$ nilainya adalah minus 1,346 . Hal ini menunjukkan bahwa jika variabel PDRB Per Kapita mengalami kenaikan 1 persen, maka jumlah penduduk miskin mengalami penurunan sebesar 1,346.

\section{Uji Signifikansi Parsial (Uji $t$ )}

Dari hasil pengujian statistik seperti terlihat dalam Tabel 1, dengan $\alpha=5$ persen dan degree of freedom $(\mathrm{df})=7(\mathrm{n}-\mathrm{k}=10-3)$, diperoleh nilai $t$-tabel untuk pengaruh ratarata lama sekolah, dan PDRB Per Kapita terhadap jumlah penduduk miskin di Provinsi 
Aceh tahun 2007-2016 adalah sebesar 1,895. Didasarkan pada nilai $t$-hitung $<$ t-tabel $(0,778$ $<1,895)$, atau karena nilai Sig. $t$ dari variabel rata-rata lama sekolah $(0,462)$ lebih besar dari $\alpha(0,05)$, maka dinyatakan bahwa $\mathrm{H}_{0}$ diterima. Hal ini berarti secara parsial, tidak ada pengaruh signifikan antara variabel $X_{l}$ (ratarata lama sekolah) terhadap variabel dependen (jumlah penduduk miskin). Jadi dapat disimpulkan bahwa rata-rata lama sekolah secara parsial berpengaruh secara tidak signifikan terhadap jumlah penduduk miskin di Provinsi Aceh.

Kemudian, berdasarkan hasil dalam Tabel 1, hasil uji parsial untuk variabel $\mathrm{X}_{2}$ (PDRB per kapita) diperoleh nilai t-hitung $>$ $t$-tabel $(5,605>1,895)$, atau karena nilai Sig. $t$ dari PDRB per kapita $(0,001)$ lebih kecil dari $\alpha(0,05)$ dengan arah koefisien negatif, maka dinyatakan bahwa $\mathrm{H}_{0}$ ditolak. Hal ini berarti secara parsial, ada pengaruh signifikan antara variabel $X_{2}$ (PDRB per kapita) terhadap variabel dependen (jumlah penduduk miskin). Jadi dapat disimpulkan bahwa PDRB per kapita secara parsial berpengaruh negatif dan signifikan terhadap jumlah penduduk miskin di Provinsi Aceh.

\section{Uji Signifikansi Simultan (Uji F)}

Dari hasil pengujian statistik seperti terlihat dalam Tabel 1, dengan $\alpha=5$ persen dan degree of freedom $(\mathrm{df})=7(\mathrm{n}-\mathrm{k}=10-3)$, diperoleh nilai $F$-tabel sebesar 4,737. Berdasarkan F-hitung $>$ F-tabel (18,515 > $4,737)$, atau karena nilai Sig. $F(0,002)$ lebih kecil dari $\alpha(0,05)$, dinyatakan bahwa $\mathrm{H}_{0}$ ditolak. Hal ini berarti bahwa variabel $X_{1}$ (rata-rata lama sekolah) dan variabel $X_{2}$ (PDRB per kapita) secara simultan memiliki pengaruh bersifat signifikan terhadap variabel dependen (jumlah penduduk miskin) di Provinsi Aceh. Jadi dapat disimpulkan bahwa rata-rata lama sekolah dan PDRB per kapita secara simultan berpengaruh signifikan terhadap jumlah penduduk miskin di Provinsi Aceh.

\section{Koefisien Determinasi $\left(\mathbf{R}^{2}\right)$}

Berdasarkan dari hasil analisis regresi pada Tabel 1, diperoleh nilai $R^{2}$ atau $R$-Square sebesar 0,841. Hal ini menunjukkan bahwa besaran kontribusi atau sumbangan pengaruh variabel independen (rata-rata lama sekolah dan PDRB per kapita) terhadap variabel dependen (jumlah penduduk miskin) adalah sebesar 84,1 persen. Sedangkan selebihnya sebesar 15,9 persen dipengaruhi variabelvariabel lain yang tidak dimasukkan ke dalam model penelitian ini, seperti pengangguran, produktivitas tenaga kerja, dan sebagainya.

\section{KESIMPULAN}

Berdasarkan hasil-hasil penelitian dan pembahasan, maka dapat disimpulkan sebagai berikut. Pertama, hasil regresi menyatakan bahwa rata-rata lama sekolah memiliki pengaruh bersifat positif terhadap jumlah penduduk miskin di Provinsi Aceh; sementara PDRB per kapita memiliki pengaruh bersifat negatif terhadap jumlah penduduk miskin di Provinsi Aceh. Kedua, hasil pengujian parsial menyatakan bahwa rata-rata lama sekolah memiliki pengaruh yang tidak signifikan terhadap jumlah penduduk miskin di Provinsi Aceh, sementara PDRB per kapita memiliki pengaruh yang signifikan terhadap jumlah penduduk miskin di Provinsi Aceh. Ketiga, hasil pengujian simultan menyatakan bahwa rata-rata lama sekolah dan PDRB per kapita berpengaruh signifikan terhadap jumlah penduduk miskin di Provinsi Aceh. Keempat, hasil koefisien determinasi menunjukkan bahwa rata-rata lama sekolah dan PDRB per kapita memiliki kontribusi terhadap variasi dari jumlah penduduk miskin sebesar 84,1 persen; sedangkan selebihnya dipengaruhi oleh variabel-variabel lain yang tidak di masukkan ke dalam model penelitian ini, misalnya pengangguran ataupun produktivitas tenaga kerja.

Berdasarkan kesimpulan yang telah diuraikan, maka dikemukakan beberapa saran berikut. Pertama, perlu adanya perhatian lebih dari Pemerintah Aceh terhadap pendidikan di Provinsi Aceh. Tujuan ini dapat dicapai melalui perbaikan kualitas dan pelayanan di bidang pendidikan. Dengan kata lain, akan tercipta kesejahteraan masyarakat yang lebih baik dan jumlah penduduk miskin akan semakin berkurang. Kedua, hendaknya ke 
depan peningkatan PDRB per kapita ini dapat diimbangi dengan pemerataan pembangunan yang berorientasi pada pemerataan tingkat pendapatan. Selanjutnya, diupayakan menggerakkan sektor-sektor perekonomian agar lebih banyak memberikan kontribusi bagi pertumbuhan ekonomi di Provinsi Aceh.

\section{DAFTAR PUSTAKA}

Arka, S. 2014. Analisis Pengaruh Pendidikan, PDRB per Kapita dan Tingkat Pengangguran terhadap Jumlah Penduduk Miskin Provinsi Bali tahun 2007-2013. Jurnal Ekonomi Pembangunan. Vol. 4, No. 5, hal. 547-549.

Arsyad, L. 2010. Ekonomi Pembangunan. Yogyakarta: STIE YKPN.

Badan Pusat Statistik. 2017. Aceh dalam Angka. http://aceh.bps.go.id

Badan Pusat Statistik. 2017. Indeks Pembangunan Manusia. Provinsi Aceh.

Badan Pusat Statistik. 2017. Produk Domestik Bruto. Provinsi Aceh.

Ghozali, I. 2011. Aplikasi Analisis Multivariate dengan Program SPSS. Semarang: BP Undip.

Hikmat, H. 2004. Strategi Pemberdayaan Masyarakat. Bandung: Humaniora.

Mahsunnah, D. 2015. Analisis Pengaruh Jumlah Penduduk, Pendidikan, dan Pengangguran terhadap kemiskinan di Jawa Timur. Jurnal Ekonomi Unesa Surabaya. Vol. 3, No. 1, hal. 11.

Mega, I.A.S. dan Yuliarmi, N.N. 2013. Beberapa Faktor yang Memengaruhi Tingkat Kemiskinan di Provinsi Bali .Jurnal Ekonomi Pembangunan Fakultas Ekonomi dan Bisnis Universitas Udayana. Vol. 2, No. 4, hal. 445- 446.

Mudrajat, K. 2006. Ekonomi Pembangunan: Teori, Masalah, dan Kebijakan. Yogyakarta: UPP AMP YKPN.
Pratiwi, S. 2014. Pengaruh PDRB Per Kapita, Pendidikan, dan Produktivitas Tenaga Kerja terhadap Kemiskinan di Provinsi Bali Tahun 1996-2012. Jurnal Ekonomi Pembangunan. Vol. 3, No. 10, hal. 437.

Rohman, A. 2009. Memahami Pendidikan dan Ilmu Pendidikan. Yogyakarta: LBM.

Sasana, H. 2006. Produk Domestik Bruto dan Strukturnya. Diklat Teknis Perencanaan Pembangunan Ekonomi Daerah Propinsi Jawa Tengah. Oktober-November. Semarang.

Sugiyono. 2013. Statistik untuk Penelitian. Jawa Barat: CV. Alfabeta.

Sukirno, S. 2006. Ekonomi Pembangunan. Edisi Kedua. Jakarta: Kencana.

Sukmaraga, P. 2011. Analisis Pengaruh Indeks Pembangunan Manusia, PDRB per Kapita dan Jumlah Pengangguran terhadap Jumlah Penduduk Miskin di Provinsi Jawa Tengah tahun 2008. Jurnal Ekonomi Universitas Diponegoro. Vol. 2, No. 5, hal. 20-21.

Todaro, M.P. 2006. Pembangunan Ekonomi di Dunia Ketiga. Jakarta: Erlangga.

Todaro, M.P. dan Smith, S.C. 2006. Pembangunan Ekonomi. Jilid I. Edisi Kesembilan. Jakarta: Erlangga.

Wiguna, V.I. 2013. Analisis Pengaruh PDRB, Pendidikan dan Pengangguran terhadap Kemiskinan di Provinsi Jawa Tengah. Jurnal Ilmu Ekonomi. Vol. 7, No. 3, hal. 30-32.

Wishnu, B.M. 2011. Analisis Pengaruh Jumlah Penduduk, PDRB, IPM, Pengangguran terhadap Tingkat Kemiskinan di Jawa Tengah. Jurnal Imu Ekonomi dan Studi Pembangunan, Fakultas Ekonomi Universitas Diponegoro. Vol. 6, No. 1, hal. 12- 13. 